used at all stages of teaching listening, given the level of language proficiency of students and duration of the text.

The contents and type of acoustic material used to develop tasks for listening, plays an important role at every stage of formation and development of skills in listening - level perception to a critical level of understanding of the text. The transition to the perception and comprehension of more difficult, from the point of view of linguistic material, and more meaningful texts leads to the formation and improvement of skills on a completely different level of understanding of the text.

On the basis of approaches to the selection of audio material and taking into account the fact that the complex of tasks for teaching listening comprehension of students learning English as a second language is aimed at formation not only auditive competence, but also sociocultural, linguistic-cultural and intercultural competences, the basic criteria for the selection of sound material for the development of complex are outlined: a) language proficiency; b) level of understanding of the text; c) authenticity; d) variability; e) matching purpose and type of listening; f) information and cultural richness; g) tolerance.

Key words: English, listening, listening skills, listening competence, text, authentic text, selection criteria, listening materials.

УДК 378.147:378.046-021.28-057.212

Сумський державний педагогічний університет імені A.C. Макаренка ORCID ID 0000-0002-8863-5603 Штика Юрій

Сумський державний педагогічний університет імені А.C. Макаренка ORCID ID 0000-0002-6187-2860

DOI 10.24139/2312-5993/2019.07/224-233

\title{
ЗМІШАНЕ НАВЧАННЯ У ПРОЦЕСІ МАГІСТЕРСЬКОї ПІДГОТОВКИ МАЙБУТНЬОГО МЕНЕДЖЕРА ОСВІТИ
}

У даний час електронне навчання стало невід'ємною частиною університетської освіти. Зазначимо, що одною з найефективніших моделей сучасної вищої освіти є змішане навчання, яке поєднує традиційні заняття в класі $з$ елементами дистанційного навчання та широко використовує сучасні інформаційні технології. Досліджено, що викладачам потрібен професійний розвиток і підтримка, щоб підготуватися до успішної розробки й викладання змішаних курсів. Відмітимо, що змішані програми є ефективними в наданні майбутньому менеджеру освіти можливості вчитися на роботі та співпрацювати з іншими вчителями, впливали на практику в класі. Наше дослідження підтверджує думку, що змішане навчання $\epsilon$ життєздатною моделлю для розвитку майбутнього менеджера освіти в процесі магістерської підготовки.

Ключові слова: змішане навчання, інформачійно-комунікаційні технології, онлайн курс, дистанційна освіта, аудиторні заняття, електронне навчання, самостійне навчання. 
Постановка проблеми. Сучасний етап розвитку суспільства характеризується активним упровадженням засобів нових інформаційних технологій в усі сфери людської діяльності. Однак, стрімкі темпи розвитку технічних засобів і програмного забезпечення вимагають не менш стрімких темпів модернізації всіх компонентів системи освіти.

Однією з проблем освіти справедливо вважають протиріччя між характером професійної діяльності сучасного менеджера освіти в умовах все більш зростаючого обсягу інформації, інтенсивного впровадження та використання засобів інформаційних і комунікаційних технологій (IKT) та традиційним рівнем навчання у процесі магістерської підготовки.

Сучасні тенденції розвитку професійної освіти, пов'язані з уведенням нових державних освітніх стандартів, інформатизацією сфери освіти, переорієнтацією технологій навчання на самостійну дослідницьку роботу, указують на те, що вдосконалення системи професійної магістерської підготовки майбутнього менеджера освіти неможливо без упровадження нових технологій навчання, Інтернету, e-learning, систем управління навчанням, а також без підвищення рівня розвитку професійних якостей фахівця як необхідної передумови компетентності випускника-магістра за спеціальністю «073 Менеджмент».

Вважаємо, що з усіх різновидів е-learning особливу роль набуває змішане навчання, яке для сучасного розвитку як системи освіти в цілому, так і локального магістерського процесу набуває актуальності.

Аналіз актуальних досліджень. Проблемі формування моделі фахівця присвячено дослідження І. Беха, І. Зязюна, В. Єльникової, Л. Козак, А. Маркової, О. Мармази, О. Романовського, В. Семиченко, С. Сисоєвої, О. Спіріна, Н. Тализіної, В. Ягупова та інших науковців.

Упровадженню моделі змішаного навчання в системі освіти присвячені праці вітчизняних (Є. Желнова, О.Кривонос, В.Кухаренко, М. Нікітіна, А. Стрюк, Ю.Триус, Г. Чередніченко, Л. Шапран та інших) та зарубіжних (I. Allen, B. Barrett, J. Bersin, C. Bonk, Di Clark, C. Dziuban, R. Garrett, S. Kmnar, A. Picciano, P. Sharma, P. Shea, A. Siddiqi, M. Tammelin, P. Valiathan) науковців.

Метою статті $€$ порівняльний аналіз традиційної технології навчання та змішаного навчання майбутнього менеджера освіти у процесі магістерської підготовки, а також розгляд можливості підвищення ефективності освітнього процесу за рахунок інтеграції інформаційних технологій в умовах педагогічного закладу вищої освіти.

Методи дослідження: для розв'язання поставлених завдань використано методи теоретичного аналізу: вивчення й аналіз науковометодичної літератури, навчальних програм, посібників, узагальнення інформації для визначення теоретико-методологічних основ дослідження.

Виклад основного матеріалу. Нині вища школа України зазнає серйозних перетворень. Спостерігається активність спроб модифікації 
традиційних форм навчання. До сприятливих факторів означеного напряму можна віднести: тотальну інформатизацію суспільства; упровадження інформаційно-комунікаційних технологій у процес магістерської підготовки майбутнього менеджера освіти; перехід до особистісної парадигмі в освіті. В епоху швидкого обміну інформацією суспільству необхідні фахівці, що володіють мобільністю та автономністю, здатні самостійно знайти, відібрати й обробити необхідну інформацію, швидко знайти вихід із проблемної ситуації, постійно вдосконалювати власні професійні компетентності. У цих умовах система традиційного навчання не може повною мірою реалізувати запити суспільства, а вимоги держави не можуть бути реалізовані без кардинальних змін системи вищої освіти.

Вважаємо, що одним із можливих шляхів вирішення означеної проблеми може стати технологія blended learning, або змішане навчання, що поєднує сильні сторони традиційних форм навчання та переваги дистанційних технологій у процесі магістерської підготовки. Іншими словами, змішане навчання $€$ ефективним способом вирішення проблеми розбіжності між вимогами сучасного суспільства та можливістю вищої освіти їм відповідати.

У ході дослідження нами узагальнено різні підходи науковців щодо визначення поняття «змішане навчання».

Уперше основні принципи змішаного навчання застосовувалися ще в шістдесятих роках XX століття в корпоративній та вищій освіті, але сам термін уперше використано в 1999 році, коли американський Інтерактивний Навчальний Центр розпочав випуск програмного забезпечення, призначеного для викладання через Інтернет.

На відміну від багатьох інших педагогічних технологій, змішане навчання не має конкретного авторства та складалося багато в чому спонтанно, у результаті численних спроб змінити існуючі методи і принципи навчання. Така спонтанність і багатофакторність розвитку змішаного навчання викликає складності при аналізі означеної технології, які починаються зі спроб сформулювати чітке визначення.

у 2006 р. у книзі «Довідник змішаного навчання» з'явилося перше досить чітке визначення змішаного навчання, що відображає його основні особливості: «Змішане навчання - це система навчання, заснована на поєднанні очного навчання (навчання віч-на-віч) та навчання комп'ютерними засобами» (Bonk, 2006).

що стосується змісту змішаного навчання, у його складі можна виділити три компоненти: 1) безпосередній контакт з викладачем під час традиційних аудиторних занять у процесі магістерської підготовки;

2) самостійна робота студентів в електронному середовищі (виконання пошукових завдань, квестів, проектів, тестів тощо); 
3) групове електронне навчання (вебінари, он-лайн конференції, вікі та інше) (Bonk, 2006).

Зазначимо, що за визначенням вітчизняних авторів А.Стрюка, Ю. Триуса та В. Кухаренка, змішане навчання - це цілеспрямований процес здобування знань, набуття вмінь та навичок в умовах інтеграції авдиторної та позаавдиторної навчальної діяльності суб'єктів освітнього процесу на основі впровадження і взаємного доповнення технологій традиційного, електронного, дистанційного та мобільного навчання за наявності самоконтролю студента за часом, місцем, маршрутами та темпом навчання (Кухаренко, 2016).

Таким чином, змішане навчання є сучасним універсальним способом освіти, яке поєднує в собі технології традиційного й електронного навчання і відповідає індивідуальним вимогам студента-майбутньому менеджеру освіти.

Залежно від ступеня насиченості освітнього процесу онлайнтехнологіями, доставки контенту і характеру взаємодії учасників, експерти розрізняють:

- традиційне навчання (без використання електронних технологій);

- традиційне навчання з веб-підтримкою (1-29 \% курсу реалізується в мережі: доставка контенту, мінімальна взаємодія через LMS при виконанні (РC);

- змішане навчання-blended-learning (30-79 \% курсу реалізується в мережі: комбінує навчання в авдиторії з заняттями в мережі);

- повне онлайн навчання (більше 80 \% курсу в мережі, часто зовсім без стаціонарної взаємодії) (Elaine Allen, 2013).

Безперечно, поєднання технологій традиційного та електронного навчання у процесі магістерської підготовки може відбуватися як на рівні окремого курсу, дисципліни, так і на рівні освітньої програми в цілому. Для досягнення освітніх цілей важливо, перш за все, правильно організувати відношення викладача та студентів, тобто здійснити перехід на суб'єктсуб'єктні стосунки, коли викладач стає фасилітатором, консультантом освітнього процесу, який постачає студентів стратегіями навчання й направляє їх пізнавальну діяльність.

Зазначимо, що змішане навчання засноване на гнучкому комбінуванні (у різних пропорціях залежно від характеру дисципліни) навчання в авдиторії з заняттями в мережі, елементи якого починають упроваджуватися в умовах Сумського державного педагогічного університету імені А. С. Макаренка:

1. Лекційні заняття онлайн. Можливе виведення низки лекційних курсів в онлайн навчання з використанням онлайн трансляції, онлайн вебінарів, або якісних записів лекцій у комбінації з технологіями самотестування. На першому етапі мова може йти про наскрізні курси, 
присутні в всіх ООП (освітньо-професійних програмах) соціальногуманітарних дисциплін. Масовість означених дисциплін сприятлива для створення якісного електронного контенту відеолекцій, а також може дати вагомий ефект економії авдиторного фонду та часу викладача.

2. Виведення частини практичних занять у режим вебінарів. Такі можливості вебінарів, як можливість для учасників користуватися загальним робочим столом, можливість почути відповідь будь-якого учасника, задати питання, показати власну роботи всім учасникам, провести опитування та тестування, виводить цю форму на повноцінну заміну традиційного практичного заняття. Представляється можливим практикувати заняття-вебінари для дисциплін, що не припускають використання лабораторного обладнання. Дещо обмежені можливості системи і при використанні формул і розрахунків. Однак, означена технологія, на наш погляд, може знайти застосування у процесі магістерської підготовки майбутнього менеджера освіти, дозволяючи проводити заняття у вечірній час для працюючих магістрантів.

3. Проведення проектної та групової роботи в мережі на основі використання сервісів LMS Moodle, або відкритих інструментів та сервісів (блоги, вікі, інтернет-закладки, сервіси розміщення фото, відео та ін.). Переваги мережевої організації означеного виду навчальної взаємодії очевидні: прозорість участі кожного, наочність результату робіт на будьякому етапі виконання, можливість зберегти результат та використовувати в подальшій організації освітнього процесу, зручність організації (незалежність від часу консультації, немає необхідності зустрічатися).

4. Змішана технологія проведення лабораторних робіт. Використання віртуальних лабораторних робіт як етап підготовки до реальної лР із тестуванням на отримання допуску в електронному середовищі дозволить скоротити час перебування студента в лабораторії та більш ефективно використовувати лабораторний фонд.

5. Використання комплексів самотестування на досягнення результатів навчання по дисциплінам дозволить організувати систему допуску до проміжної атестації з дисципліни з мінімальною участю викладача (означена система потребує розробки).

6. Переведення частини рейтингових балів на взаємодію 3 електронним середовищем (тести, автоматичні ІДЗ, підготовка до ВЛР, автоматичне проведення через «антиплагіат» студентських робіт до їх пред'явлення викладачеві) наближає технологію змішаного навчання до технології масових онлайн курсів (МОOC - Massive Open Online Course), що практикується на Заході).

7. Консультації в режимі вебінарів (і форумів) за спеціальним розкладом - повноцінна заміна авдиторних консультацій із низки дисциплін. 
Зазначимо, що розробка будь-якого курсу для студентів-майбутніх менеджерів освіти на основі змішаного навчання вимагає високого професіоналізму від викладача у процесі магістерської підготовки, оскільки доводиться не лише виступати в ролі консультанта-радника, координатора освітнього процесу, який організовує автономну діяльність студентів і ефективну систему контролю, а й перебувати в постійному контакті 3 майбутніми фахівцями на авдиторних заняттях, так і в електронному середовищі. При цьому мається на увазі як комп'ютерна грамотність викладача, так і знання особливостей роботи технології змішаного навчання, готовність до постійного навантаження.

Варто зазначити, що однією з важливих складових змішаного навчання $\epsilon$ технологія «перевернутого класу». Засновником освітньої технології - «peer instruction» вважається Ерік Мазур, професор фізики Гарвардського університету, володар премії Minerva, який вважає, що в сфері освіти ми прийдемо до суміші проектно-, проблемно- і командноорієнтованих підходів, peer instruction, і семінарів, які будуть варіюватися в залежності від контексту та кількості студентів в авдиторії. На нашу думку, у XXI столітті, коли роботи і комп'ютери займають багато робочих місць, нам необхідно навчати людей займати ті новаторські та креативні посади, на які комп'ютери й роботи не претендуватимуть.

Безперечно, за технологією, яку запропонував Мазур, студент оволодіває новою темою вдома, а в авдиторії працює над ії розумінням разом із однокурсниками і викладачем. Технологію Мазура почали називати «перевернутим класом» (flipped classroom), головна ідея якої полягає не в передачі інформації студенту, оскільки він отримав їі вдома, а допомозі в ії засвоєнні. Згодом Мазур створив покроковий алгоритм peer instruction, який придав методу конкретну форму (Хайден, 2015).

Таким чином, на відміну від традиційних технологій навчання у процесі магістерської підготовки, у якій введення нового матеріалу відбувається в аудиторії, а потім студенти закріплюють його в ході виконання домашньої роботи, у технології змішаного навчання відбувається перестановка означених етапів. Студенти-майбутні менеджери освіти знайомляться 3 новим матеріалом самостійно за допомогою перегляду відеолекцій, наданих викладачем або взятих із інших джерел, а в авдиторії виконуються завдання під керівництвом викладача. При цьому використовується все різноманіття форм контролю: самоконтроль в електронному середовищі (наприклад, виконання тестів з подальшою перевіркою за ключами, які стають доступними після виконання тесту), а також у процесі авдиторної роботи під контролем викладача. Важливим моментом $€$ взаємоконтроль (перевірка виконаних есе, підготовлених ситуацій, педагогічних задач, доповідей із використанням презентацій тощо), який також може проходити в різних форматах (в електронному середовищі або в авдиторії). 
У результаті означена технологія у процесі магістерської підготовки дозволяє збільшити час для безпосереднього обговорення завдань в авдиторії і, отже, на розвиток комунікативних умінь студентів. Вважаємо, що робота в електронному освітньому середовищі $\epsilon$ комфортною для студентів-майбутніх менеджерів освіти, допомагає деяким із них подолати психологічний бар'єр, невпевненість у собі, що виникає під час роботи в авдиторії, коли кожен порівнює себе з іншими студентами. Зниження рівня стресу під час роботи в електронному середовищі підвищує їх упевненість та самооцінку, що продуктивно позначається на їх участі у групових дискусіях та дебатах. Однозначно позитивним $\epsilon$ те, що в авдиторії викладач може пропонувати студентам творчі завдання, обговорення важливих професійних проблем. Вважаємо, що для того, щоб освітня технологія, заснована на принципах змішаного навчання, була ефективною, всі її компоненти повинні бути елементами однієї системи, гармонійно взаємодіяти один із одним.

Вважаємо, що під час реалізації технології змішаного навчання у процесі магістерської підготовки майбутнього менеджера освіти можливе використання різноманітних типів цифрових освітніх ресурсів і онлайнсервісів:

- системи управління навчанням (LM S, Learning Management System, наприклад, Moodle, Edmodo тощо);

- цифрові колекції навчальних об'єктів (наприклад, Єдина Колекція Освітніх Ресурсів);

- навчальні онлайн-курси (наприклад, онлайн-курси «Мобільної Електронної Школи»);

- інструменти для створення і публікації контенту і навчальних об'єктів (наприклад, конструктор тестів 1C);

- інструменти для комунікації і зворотного зв'язку (M irapolis, Скайп, Google-чат тощо);

- інструменти для співпраці (наприклад, Google Docs, Word Online тощо);

- інструменти для створення спільнот (соціальні мережі);

- інструменти планування навчальної діяльності (електронні журнали, органайзери).

3 метою впровадження елементів електронного навчання в Сумському державному педагогічному університеті імені А.С. Макаренка на кафедрі менеджменту освіти та педагогіки вищої школи розроблено електронний курс «Технології комп'ютерних мереж в управлінні організацією» для групи магістрів спеціальності 073 «Менеджмент» 2-го курсу в якості доповнення до авдиторного навчання, що безпосередньо співвідноситься з технологією blended learning. 
На жаль, часто викладачі не готові витрачати час на створення електронних продуктів у силу завантаженості під час проведення авдиторних занять, планування, перевірки письмових робіт студентів тощо, а іноді відчувають страх, коли мова заходить про освоєння нових комп'ютерних технологій. Подолавши означений бар'єр, викладач здатний усвідомити, що електронний курс може вирішувати багато завдань і компенсувати недоліки традиційної форми навчання. До переваг роботи 3 електронним курсом можна віднести такі фактори: 1) викладати онлайн значить не бути прив'язаним до якогось місця, необхідний лише доступ до Інтернет; 2) створюючи онлайн курс, потрібно буде всього лише спускатися по стрічці (пропонованих спеціальною програмою) налаштувань зверху вниз, заповнюючи порожні графи в простому інтерфейсі крок за кроком, використовуючи вже наявні сервіси та інструменти, що автоматизують означений процес. У нашому випадку вибір було зроблено на користь платформи Moodle в силу того, що вона виявилася доступною в закладі освіти та доволі простою для використання.

Метою вищеназваного електронного курсу є вивчення основних ідей та принципів роботи архітектури ЕОМ, архітектури та будови комп'ютерних мереж, взаємодії програмного та апаратного забезпечення мережних систем, використання мереж в організації роботи та керівництві установами. Він $є$ онлайн компонентом, які супроводжують основний курс із дисципліни, розрахований на 30 авдиторних години. Особливості технології змішаного навчання у процесі магістерської підготовки описано вище, тому, на наш погляд, докладно на цьому зупинятися недоцільно. Пропонуємо коротку характеристику означеного курсу та результати зворотного зв'язку, здійсненого студентами-майбутніми менеджерами освіти після його проходження.

Курс «Технології комп'ютерних мереж в управлінні організацією», має статус «тільки для запрошених», таким чином, робота проводилася 3 конкретною академічною групою (12 осіб) у межах програми зазначеної дисципліни для майбутніх менеджерів освіти, які могли зареєструватися на цей курс. Тривалість курсу становить 6 тижнів (60 годин у мережі).

Кожен підрозділ електронного курсу спрямований на досягнення певних складових результатів навчання. У межах кожного тижня $\epsilon$ компонент, що забезпечує контроль, самоконтроль і взаємоконтроль досягнутих результатів, а також компоненти, що забезпечують постійну взаємодію між студентами у процесі магістерської підготовки.

Після закінчення курсу було проведено анкетування, яке показало, що майже всі студенти вважають його проведення ефективним та потрібним для професійного розвитку. Отже, у результаті роботи студенти отримали: цілісну систему знань про інформацію та інформаційні процеси, сформували навички конфігурування ПЕОМ в мережі, про адміністрування окремого комп'ютера та функціонування запам'ятовуючих пристроїв. 
Висновки та перспективи подальших розвідок. У сучасних умовах стрімкого розвитку інформаційних технологій процес магістерської підготовки у педагогічних закладах вищої освіти має гнучко та своєчасно реагувати на зміни в сучасному суспільстві, що вимагає від педагогічних закладів вищої освіти вдосконалення змісту та методики навчання відповідно до реальних умов та завдань сьогодення.

Змішане навчання $є$ пріоритетною технологією навчання в сучасних освітніх умовах, надає незаперечні переваги як для викладачів, так і для студентів-майбутніх менеджерів освіти. Способи подачі матеріалу при змішаному навчанні можуть включати авдиторні заняття (face-to-face), електронне навчання (e-learning) та самостійне навчання (self-paced learning). У ньому вдало вирішується завдання силами обмеженого числа викладачів допомогти великій кількості студентів стати «ефективними користувачами» сучасних інформаційних технологій. Зазначена технологія створює переваги для ефективного викладання курсу «Технології комп'ютерних мереж в управлінні організацією» з опорою на принцип мобільності та використання комп'ютерного навчання. Усі компоненти означеної технології гармонійно взаємодіють лише в тому випадку, якщо вони методично вірно організовані. Компоненти можуть варіюватися за обсягом та тривалістю в залежності від розв'язуваних завдань.

Перспективи подальших досліджень у цьому напрямі вбачаємо в упровадженні змішаного навчання для всіх навчальних курсів спеціальності 073 «Менеджмент» у процесі магістерської підготовки в педагогічних закладах вищої освіти.

\section{ЛІТЕРАТУРА}

Кухаренко, В. М. (2016). Теорія та практика змішаного навчання. Харків (Kukharenko, V. M. (2016). Theory and Practice of Blended Learning. Kharkiv).

Хайден, Б. (2015). Первый кавалер Минервы. 2015-04-17. The Harvard Crimson, courtesy of Harvard School of Engineering and Applied Sciences Julie Schell. Режим доступу: http://linkis.com/S1v7g. (Hajden, B. (2015). The first M inerva cavalier. 2015-04-17 The Harvard Crimson courtesy of Harvard School of Engineering and Applied Sciences Julie Schell. Retrieved from: http://linkis.com/S1v7g.

Bonk, C. J. \& Graham, C. R. (2006). Handbook of blended learning: Global Perspectives, local designs. San Francisco, CA: Pfeiffer Publishing.

Elaine, I. (2013). Allen and Jeff Seaman. Changing Course: Ten Years of Tracking Online Education in the United States. Babson Survey Research Group and Quahog Research Group.

\section{PEЗЮМЕ}

Максименко Татьяна, Штика Юрий. Смешанное обучения в процессе магистерской подготовки будущего менеджера образования.

В настоящее время электронное обучение стало неотъемлемой частью университетского образования. Отметим, что одной из самых эфрфективных моделей современного высшего образования является смешанное обучение, которое 
сочетает традиционные занятия в классе с элементами дистанционного обучения и широко использует современные информационные технологии. Доказано, что преподавателям необходимы профессиональное развитие и поддержка, чтобы подготовиться $к$ успешной разработке и преподаванию смешанных курсов. Заметим, что смешанные программы эффрективны в предоставлении будущему менеджеру образования возможности учиться на работе и сотрудничать с другими преподавателями, и влиять на практику в аудитории. Наше исследование подтверждает, что смешанное обучение является жизнеспособной моделью для развития будущего менеджера образования в прочессе магистерской подготовки.

Ключевые слова: смешанное обучение, информационно-коммуникационные технологии, онлайн курс, дистанционное образование, аудиторные занятия, электронное обучение, самостоятельное.

\section{SUM MARY}

Maksymenko Tetiana, Shtyka Yurii. Blended learning in the process of a future educational manager preparation.

Currently e-learning has become an integral part of university education. It is also an integral part of distance education, which is now rapidly developing. One of the most effective patterns of modern higher education is blended learning that combines traditional classroom activities with elements of distance training and makes a wide use of modern information technology. Therefore, blended learning is an innovative concept that embraces the advantages of both traditional teaching in the classroom and ICT supported learning including both offline learning and online learning. It has scope for collaborative learning; constructive learning and computer assisted learning (CAI). Blended learning needs rigorous efforts, right attitude, handsome budget and highly motivated teachers and students for its successful implementation. As it incorporates diverse modes, so it is complex and organizing it is a difficult task. The present paper discusses the concept of blended learning, its main features and prerequisite of its implementation in the process of a future educational manager preparation. The present paper also tries to explain that blended learning is an approach that needs to be adopted.

Blended learning, drawing from best practices in both online and face-to-face learning, is on the rise in higher education. Research shows that faculty needs professional development and support to get prepared for successfully developing and teaching blended courses. The blended programs were effective in providing a future educational manager with an opportunity for learning on the job and collaborating with other teachers, and they influenced classroom practice moderately and affected student learning to a limited extent. Our study supports the contention that blended learning is a viable model for a future educational manager development in the process of master's preparation.

Key words blended learning, information and communication technologies, online course, distance education, face-to-face classes, e-learning, self-paced learning. 